\title{
Development of Chemistry Pre-Service Teachers During Practical Pedagogical Training: Self-Evaluation vs. Evaluation by School Mentors
}

\author{
Vesna Ferk Savec* and Katarina S. Wissiak Grm \\ Faculty of Education, University Ljubljana, Kardeljeva ploščad 16, 1000 Ljubljana, Slovenia \\ * Corresponding author: E-mail: vesna.ferk@pef.uni-lj.si
}

Received: 16-08-2016

\begin{abstract}
The research presented in this article deals with the self-evaluation of $4^{\text {th }}$ year pre-service chemistry teachers' progress during their second year practical pedagogical training in chemistry teaching at primary schools (students' age 13-15 years) in comparison to the perception of their progress by their school mentors. The sample consisted of 21 pre-service teachers and 21 school mentors, in-service chemistry teachers, at primary schools. For the purpose of following to pre-service chemistry teachers' development, the pre-service teachers as well as their mentors completed the "Questionnaire for monitoring students' progress", focusing on eight characteristics of professional development during practical pedagogical training. The results reveal that student-teachers were stricter in their self-evaluation in comparison to their school mentors after their first chemistry lecture at school during the practical pedagogical training; however, after their last lecture, the evaluations were similar for most of the characteristics. The development of five randomly selected student-teachers is presented in detail from their own perspectives, as well as from their school mentors' perspectives.
\end{abstract}

Keywords: Chemistry teacher education, practical pedagogical training, pre-service chemistry teachers, in-service chemistry teachers, school mentors

\section{Introduction}

Within the framework of the education of pre-service teachers, practical pedagogical training is viewed as a crucial component in their professional development as teachers. ${ }^{1,2}$ Hascher and Hagenauer ${ }^{3}$ reviewed different terms referring to the various forms of practical training in teacher education, e.g. teaching practicum, student teaching, field experiences, teaching practice, clinical training, clinical teacher education, (guided) teaching experiences, internship, school practicum, school-based teacher education, and school placement. In this article, we use the term practical pedagogical training (PPT), which we define as a mandatory module in a pre-service teachereducation programme that takes place at school under the supervision of a school mentor, who is an in-service teacher of a specific school subject. PPT is aimed at providing pre-service teachers with an opportunity to gain experience in the classroom through their own teaching and/or coteaching facilitated by continuous feedback about their teaching from their school mentor.
PPT and their contribution to the learning of pre-service teachers have been an area of interest to researchers, teacher educators and teachers. Some studies have focused on pre-service teachers development, their beliefs, experiences, and expectations, as well as the challenges and their concerns relating to the PPT. ${ }^{4-8}$ Another group of studies focused on mentors and the mentoring provided by experienced teachers in schools. ${ }^{9-12}$ A third group of studies focused on the work of teacher educators in finding ways to support pre-service teachers in developing their teaching of specifics subject in school environments. ${ }^{13-16}$

According to the literature review of Lawson et al., ${ }^{17}$ a broad range of factors play roles in the PPT process for pre-service teachers. Among the outcomes in their review, the collaboration between student-teachers and mentors emerged as significant for the professional and individual development of pre-service teachers. It was pointed out that mentors' feedback is also a crucial aspect of the mentor-pre-service teacher relationship, from the viewpoint of prospective teachers. 
Another viewpoint highlights pre-service teachers' individual differences and the effects of the characteristics of individual student-teachers on the processes during PPT and their outcomes. ${ }^{18-20}$

Hascher and Kittinger ${ }^{21}$ proposed students-teachers' learning and performance model to explain learning in PPT. Their model assumes that the quality of learning processes and learning outcomes during PPT is influenced by structural aspects (e.g. single or tandem placement, shortor long-term practicum), organizational aspects (e.g. university-school cooperation, school mentor professionalization), and social aspects (e.g. school social climate, teacher candidate's integration into the teaching staff). Their model also recognizes the role of individual factors of pre-service teachers such as cognition (e.g. pre-knowledge, attitudes, beliefs), motivation (e.g. interest, goal orientation), and emotions (e.g. enjoyment, anger) to contribute to the learning process. The model as well recognizes that factors at different levels (e.g. the culture of teacher education at the macro-level versus the teacher candidate-mentor interaction at the micro-level) co-determine the outcomes of teacher education..$^{20,21}$

This article focuses on the self-evaluation of preservice chemistry teachers' progress during their PPT in primary schools in comparison to the perception of their progress by their school mentors, who observed their teaching during PPT and provided feedback after each of the lessons.

\section{The Context and the Purpose of the Study}

At the Faculty of Education of the University of Ljubljana, Slovenia, the PPT of pre-service chemistry teachers commences in the $3^{\text {rd }}$ year of tertiary education and continues in the $4^{\text {th }}$ year. PPT is organized in collaboration between teacher educators at the university and selected primary school mentors. It is conducted in primary schools in Slovenia. Within the framework of PPT, stu- dent-teachers prepare lesson plans and teach chemistry in the $8^{\text {th }}$ and $9^{\text {th }}$ years of Slovenian primary schools (the students are 14 to 15 years old). At selected primary schools, pre-service teachers have a school mentor (experienced in-service chemistry teacher). The role of the school mentor is to give directions prior to the commencement of PPT for successful inclusion in the current teaching plan, within the framework of which the student-teachers conduct and attend lessons during the time of PPT. The school mentor is also present during all of the lessons that the student-teacher conducts and, directly after each lesson, provides the student-teacher with feedback on the positive aspects of the individual performance, as well as on necessary improvements.

In order to improve pre-service teachers' learning possibilities during PPT, we attempted to adjust PPT to pre-service teachers' suggestions based on previous research. ${ }^{7}$ Specifically, we have considered the following main proposals given by the pre-service chemistry teachers: ${ }^{7}$ (1) longer PPT, (2) independent choice of location and school for PPT, and (3) the possibility of doing PPT in several schools in cooperation with a number of different school mentors. The changes that have been introduced in PPT with regard to student-teachers' suggestions ${ }^{7}$ are presented in Table 1.

This article deals with pre-service chemistry teachers', $4^{\text {th }}$-year student-teachers, development during their second-year experience with teaching during their PPT. The article focuses on the monitoring of pre-service chemistry teachers' first and the last lecture during their PPT based on their own and their school mentors' perceptions of eight characteristics of student-teachers' development measured by the "Questionnaire for monitoring students' progress". ${ }^{7}$

The study addresses the following research question:

How do pre-service chemistry teachers evaluate their development in comparison with their school mentors on their second-year experience with teaching during their PPT?

Table 1. Changes that have been introduced in PPT with regard to student-teachers' suggestions

\begin{tabular}{|c|c|c|}
\hline $\begin{array}{l}\text { Student-teachers' suggestions for optimization } \\
\text { of PPT based on the evaluation of } \text { PPT }^{7}\end{array}$ & $\begin{array}{l}\text { State of PPT in the } 2008 / 09 \\
\text { academic year }{ }^{7} \text { - before optimization }\end{array}$ & $\begin{array}{l}\text { State of PPT in the } 2014 / 15 \\
\text { academic year - after optimization }\end{array}$ \\
\hline (1) Student-teachers' suggestion for a longer PPT; & - Five school days per academic year; & - Ten school days per academic year; \\
\hline $\begin{array}{l}\text { (2) Student-teachers' suggestion } \\
\text { for an independent choice } \\
\text { of location and school for PPT; }\end{array}$ & $\begin{array}{l}\text { - Seven primary schools } \\
\text { - Within the Ljubljana Urban } \\
\text { Municipality, Slovenia; } \\
\text { - Schools chosen by the University; } \\
\text { - 2-3 student-teachers conducted } \\
\text { PPT simultaneously at the same } \\
\text { school at the time; }\end{array}$ & $\begin{array}{l}\text { - Twenty-one primary schools } \\
\text { (for } 4^{\text {th }} \text { year student-teachers); } \\
\text { - All Slovenian regions; } \\
\text { - Schools chosen independently } \\
\text { by each of the student-teachers; } \\
\text { - One student conducted PPT } \\
\text { at each of the schools; }\end{array}$ \\
\hline $\begin{array}{l}\text { (3) Student-teachers' suggestion for the } \\
\text { possibility of doing PPT in several schools } \\
\text { in cooperation with a number of different } \\
\text { school mentors; }\end{array}$ & $\begin{array}{l}\text { - Each of the student-teachers had the } \\
\text { possibility to collaborate with one } \\
\text { school mentor in the same academic } \\
\text { year in the framework of PPT; }\end{array}$ & $\begin{array}{l}\text { - Each of the student-teachers had the } \\
\text { possibility to collaborate with several } \\
\text { school mentors in the same academic } \\
\text { year in the framework of PPT; }\end{array}$ \\
\hline
\end{tabular}

Ferk Savec and Wissiak Grm: Development of Chemistry Pre-Service Teachers During ... 


\section{Method}

\section{1. Instruments}

For the purpose of the investigation, the "Questionnaire for monitoring students' progress" ${ }^{\text {"7 }}$ was applied. The questionnaire showed appropriate internal consistency (Cronbach $\alpha=0.89$ ). ${ }^{7}$

The questionnaire enables reflection on pre-service teachers' development during PPT, in particular with regards to the following eight student-teacher characteristics:

(1) the pre-service teacher's self-esteem while conducting the lessons

-referred to as Self-esteem in this article,

(2) the pre-service teacher's ability to establish discipline in class -referred to as Discipline in this article,

(3) the suitability of the pre-service teacher's explanation of the chemistry topic taught

-referred to as Explanation in this article,

(4) the ability of the pre-service teacher to anticipate the appropriate amount of material to present during the lesson -referred to as The amount of contents in this article,

(5) the pre-service teacher's experimental skills -referred to as Experimental skills in this article,

(6) the pre-service teacher's expertise in providing an appropriate response to the students

-referred to as Response in this article,

(7) the pre-service teacher's ability to involve students actively

- referred to as Active student's involvement in this article, and

(8) the pre-service teacher's self-dependence in preparing for the lesson

-referred to as Self-dependence in this article.

Pre-service teachers and their school mentors evaluated pre-service teachers' development regarding each of the above-listed specific characteristics with a mark in the range $1-5$, in which " 1 " represents the lowest studentteachers" competence and " 5 " the highest student-teachers' competence.

\section{2. Sample}

The sample consisted of student-teachers $(N=21)$ enrolled in the 2014/15 academic year in the $4^{\text {th }}$ year of the undergraduate programmes "Chemistry and Biology" or "Chemistry and Physics" or "Chemistry and Home Economics" at the Faculty of Education, University of Ljubljana. The student-teachers involved were predominantly female $(N=20)$, and only one was male $(N=$ $1)$; their average age was 23.91 years. Due to their future profession, they are referred to as pre-service teachers or student-teachers in this article.

In addition to the pre-service teachers their school mentors, experienced in-service chemistry teachers $(N=21)$, from the twenty-one primary schools where PPT took place, were also involved in this study. All participating school mentors were female, and their average age was 46.20 years. In average, they had 20.81 years of experience in the teaching of the subject of chemistry in primary schools.

In this study, the development of five $4^{\text {th }}$ year pre-service chemistry teachers, who were chosen from the sample via random selection, is presented in detail from their own perspectives as well as from their school mentors' perspectives. Each student-teacher in PPT only had one mentor and visited only one school. In order to assure anonymity of student-teachers, their names - presented in the results of the article - are pseudonyms, i.e. Ina (female), Sara (female), Jan (male), Mara (female) and Ula (female).

\section{3. Data Collection}

The PPT for $4^{\text {th }}$ year student-teachers was conducted in April 2015 at twenty-one primary schools throughout Slovenia. Every student spent two weeks (10 days) at an independently selected primary school, which was their second year experience of teaching chemistry. Each student-teacher monitored their own progress every day during PPT with the aid of the "Questionnaire for monitoring students' progress"7. The school mentors evaluated student-teachers' development by the use of "Questionnaire for monitoring students' progress"7 twice - after their first and last chemistry lecture during PPT.

\section{4. Data Analysis}

\section{4. 1. Analysis of the "Questionnaire for Monitoring Students' Progress “}

The results collected from pre-service chemistry teachers and their school mentors in the "Questionnaire for monitoring students' progress"7 were entered into MS Excel, and appropriate calculations and figures were prepared. Further analysis was conducted using the Statistical Package for the Social Sciences (SPSS), version 21. The nonparametric test Wilcoxon Ranks Test (Z) was used to evaluate significant differences in perceptions of studentteachers' characteristics by pre-service teachers in comparison to their school mentors. Pre-service teachers' comments accompanying the numerical data were transcribed.

\section{Results and Discussion}

At the pre-service teachers' first teaching of chemistry at school during their second year PPT, their school mentors evaluated the student-teachers' characteristics with higher values in comparison to pre-service teachers self-evaluation as can be seen from the mean values in Table 2. At the pre-service teachers' final teaching of chemistry at school during their second-year PPT, studentteachers' competences were again investigated. From the 
Table 2. The mean values for eight characteristics measured by "Questionnaire for monitoring students' progress" from student-teachers' and school mentors' perspectives after their first and final presentation during PPT

\begin{tabular}{|c|c|c|c|c|c|c|c|c|}
\hline \multirow{3}{*}{ Characteristic } & \multicolumn{4}{|c|}{ First presentation in PPT } & \multicolumn{4}{|c|}{ Final presentation in PPT } \\
\hline & \multicolumn{2}{|c|}{ Pre-service-teachers } & \multicolumn{2}{|c|}{ School mentors } & \multicolumn{2}{|c|}{ Pre-service-teachers } & \multicolumn{2}{|c|}{ School mentors } \\
\hline & Mean & SD & Mean & SD & Mean & SD & Mean & SD \\
\hline Self-esteem & 3.39 & 0.70 & 4.39 & 0.61 & 4.92 & 0.26 & 4.72 & 0.46 \\
\hline Discipline & 3.33 & 1.19 & 4.17 & 0.92 & 4.94 & 0.24 & 4.94 & 0.24 \\
\hline Explanation & 3.78 & 0.73 & 3.94 & 0.64 & 4.83 & 0.38 & 4.72 & 0.46 \\
\hline The amount of contents & 3.39 & 1.24 & 4.44 & 0.70 & 4.72 & 0.46 & 5.00 & 0.00 \\
\hline Experimental skills & 3.72 & 1.13 & 4.00 & 0.69 & 4.72 & 0.46 & 4.56 & 0.51 \\
\hline Response & 4.11 & 0.68 & 4.22 & 0.65 & 4.69 & 0.46 & 4.78 & 0.43 \\
\hline Active student's involvement & 3.44 & 1.10 & 4.39 & 0.78 & 4.72 & 0.46 & 4.44 & 0.70 \\
\hline Self-dependence & 3.89 & 1.23 & 4.33 & 0.69 & 4.83 & 0.38 & 4.50 & 0.62 \\
\hline
\end{tabular}

mean values in Table 2, it can be determined that their perception of their own competence was closer to that of their school mentor's at that time.

For the pre-service teachers' first teaching of chemistry, Wilcoxon Ranks Test showed significant differences in perception between pre-service teachers and their school mentors about the future teachers competence in four characteristics: Self-esteem $(Z=-2.924, p=0.003)$, Discipline $(Z=-2.223, p=0.026)$, The amount of contents $(Z=-2.799, p=0.005)$, Active student's involvement $(Z=$ $-2.315, p=0.021)$. In contrast, no significant differences were found in the other four characteristics Explanation $(Z$ $=-0.566, p=0.572)$, Experimental skills $(Z=-0.366, p=$ $0.714)$, Response $(Z=-0.540, p=0.589)$, Self-dependen-

Table 3: Ina's self-evaluation of her skills and knowledge in specific fields at her first and final presentation during their PPT in comparison with the evaluation of her school mentor

Ina's self-evaluation of her skills and knowledge [Scale 1 to 5]

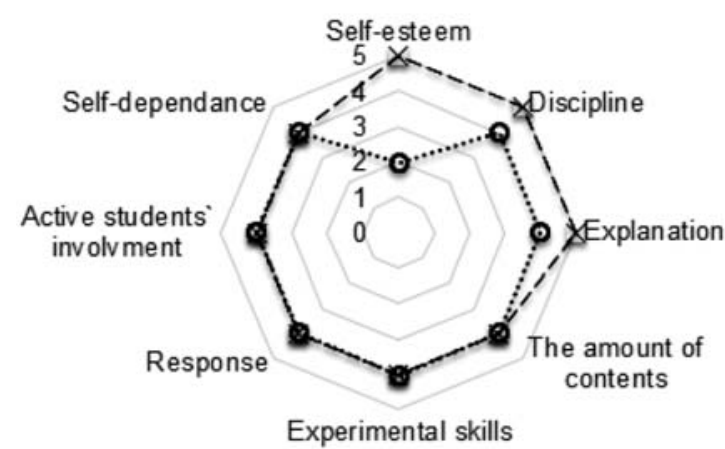

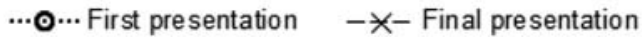

To the question "How did you perceive the course of the lesson in the role of chemistry teacher?" Ina explained:

\section{After her first presentation:}

"After a year outside the school climate, I did not feel very selfconfident, since I had not met students yet."

\section{After her final presentation:}

"During the practical pedagogical training, I had gained selfconfidence, had a better feeling regarding explaining teaching topic and was better when came to establishing discipline in the class."
Teacher's evaluation of Ina's skills and knowledge [Scale 1 to 5]

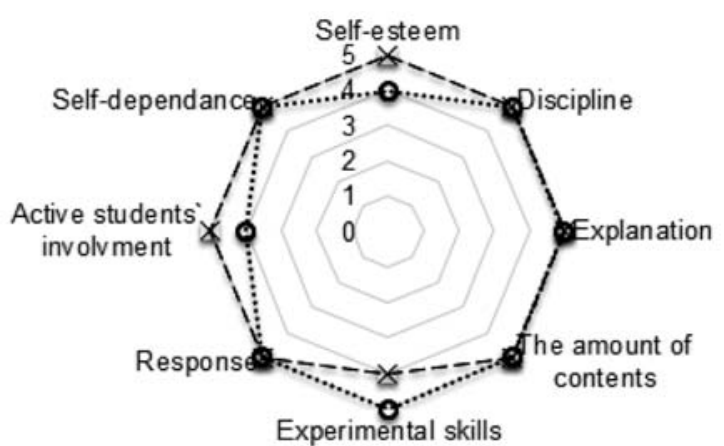

...... First presentation $\quad-\star \star-$ Final presentation

To the question "How did you perceive the course of the lesson with Ina in the role of chemistry teacher?" Ina's school mentor explained:

\section{After her first presentation:}

"She presented the new chemistry topic thoroughly through the experimental work. Ina's explanation was clear and she was able to adapt to the students' rhythm of knowledge comprehension."

\section{After her final presentation:}

"During the lessons, she succeeded in applying all the teaching goals designed in advanced. Students were able to be actively involved in the process of presenting the new chemistry topic. Experimental work was carried out in a correct and appropriate manner. The content of the chemistry topic was properly introduced.“ 
ce $(Z=-1.310, p=0.190)$. Based on these results, it can be summarized that pre-service teachers are more realistic in estimating their competence for explanations of the chemistry topic taught, their experimental skills, their ability for providing an appropriate response to the students in the classrooms and their self-dependence in preparing for the lesson. However, pre-service teachers seem to be stricter in evaluation of their appearance of self-esteem while conducting the lessons and ability to establish discipline in class during lessons, also their ability to anticipate the appropriate amount of contents to present during the lesson and to actively involve students seem to be underestimated with regard to the perception of their school mentors.

For the pre-service teachers' final teaching of chemistry, the Wilcoxon Ranks Test showed significant differences in perception between pre-service teachers and their school mentors about the future teachers' competence in only one of eight characteristics, in the amount of contents $(Z=-2.236, p=0.025)$. No significant differences were found in other seven characteristics: Self-esteem $(Z=$
$-1.536, p=0.125)$, Discipline $(Z=0.000, p=1.000)$, Explanation $(Z=-0.707, p=0.480)$, Experimental skills $(Z=$ $-0.832, p=0.405)$, Response $(Z=-1.342, p=0.180)$, Active student's involvement $(Z=-1.387, p=0.166)$, Self-dependence $(Z=-1.897, p=0.058)$. Based on these results, it can be summarized that pre-service teachers gained more realistic estimation of their competences during the time of PPT in comparison to their school mentors' perceptions.

To obtain insight into the situation of individual preservice teachers', examples of the individual evaluations of eight characteristics are presented for five student-teachers in comparison with their development as seen by their school mentors.

\section{1. Example 1: $4^{\text {th }}$-year student-teacher Ina}

After her first lesson, it is clear from Table 3 that the student Ina had perceived herself as having very little self-confidence, which was in contradiction with her teacher mentor's comprehension of her behavior. In general, the teacher mentor

Table 4. Sara's self-evaluation of her skills and knowledge in specific fields at her first and final presentation during their PPT in comparison with the evaluation of her school mentor

Sara's self-evaluation of her skills and knowledge [Scale 1 to 5]

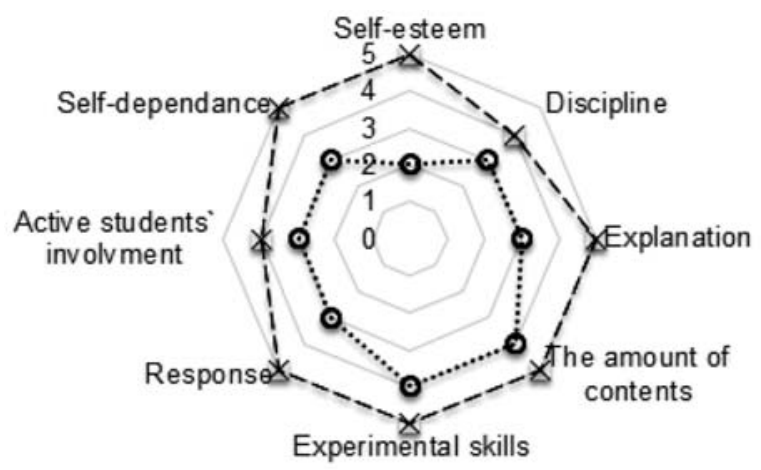

....... First presentation $\quad-\star \star$ Final presentation

To the question "How did you perceive the course of the lesson in the role of chemistry teacher?"

Sara explained:

\section{After her first presentation:}

"I was satisfied with the way I was able to carry out the teaching lesson, since I was able to ask students enough different questions. The students were also very active, since they were involved in the teaching and learning process properly."

\footnotetext{
After her final presentation:

"I feel that my ability to establish discipline in the class has improved; students are listening to me and are willing to cooperate. I also feel that I am doing better when performing experiments in the class, I am no longer frightened when demonstrating the chemical experiment in front of the students in the class."
}

Teacher's evaluation of Sara's skills and knowledge [Scale 1 to 5]

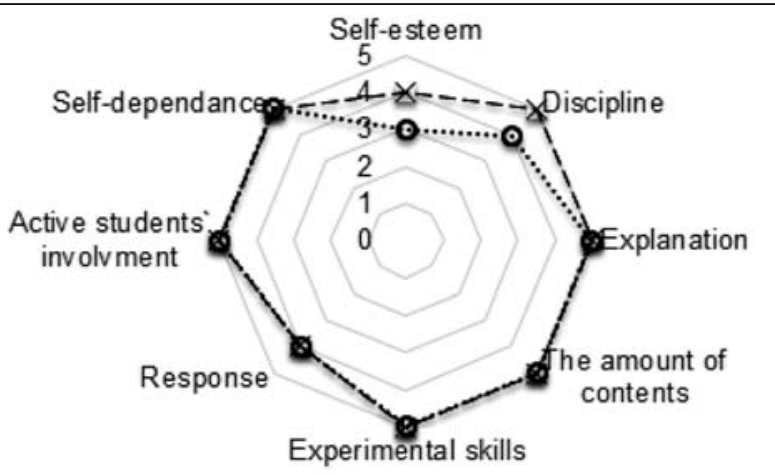

...๑... First presentation $\quad-\star *-$ Final presentation

To the question "How did you perceive the course of the lesson with Ina in the role of chemistry teacher?" Sara's school mentor explained:

\section{After her first presentation:}

"Sara was able to perform the lesson very well, involving students in the teaching and learning process. Her explanations were clear, and the lecture was designed appropriately due to the logical structure from the beginning to the end. She only could check the students intensively by reviewing their notes during the lesson."

\section{After her final presentation:}

"Sara is more confident and convincing when introducing new chemistry topics. She skillfully reacted when waiting for the experiment to occur, since the safety rules in the lab had been revised." 
had seen Ina's presence in the class as being very appropriate regarding all the significant characteristics observed.

At Ina's final presentation (Table 3) in the class during PPT, her self-evaluation opinion had improved; she saw herself in a much better light also with regard to explanation of the topics taught and establishing discipline in the class. Ina's teacher mentor's opinion was consistent with Ina's self-evaluation, however the mentor described her improvement to the highest level in all areas described by influential characteristics.

\section{2. Example 2: $4^{\text {th }}$-year student-teacher Sara}

At her first presentation (Table 4) the student-teacher Sara had seen all of her influential characteristics through self-assessment as being quite low, except regarding the chemical experiment demonstration and the ability to anticipate the appropriate amount of matter to be presented during the lesson which is not coherent with her comment, where she stated that she is quite satisfied with the lesson. Also Sara's school mentor's opinion is very positive; except regarding Sara's self-esteem, she evaluated Sara with quite high marks regarding all other influential characteristics observed.

From Table 4, it can be determined that the situation had changed significantly by Sara's last presentation during PPT. While conducting the final chemistry lesson, Sara had perceived herself to be very appropriate while grading all the influential characteristics; she only marked herself a bit lower regarding the successful involvement of

Table 5: Jan's self-evaluation of her skills and knowledge in specific fields at his first and final presentation during their PPT in comparison with the evaluation of her school mentor

Jan's self-evaluation of her skills and knowledge [Scale 1 to 5]

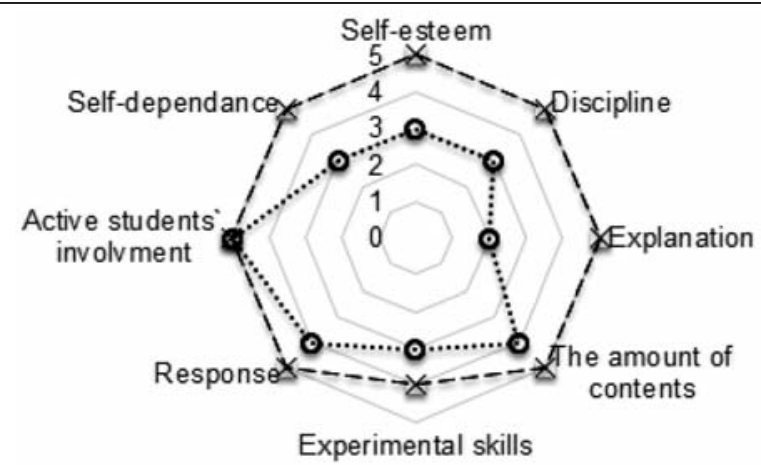

....... First presentation $\quad-x-$. Final presentation

To the question "How did you perceive the course of the lesson in the role of chemistry teacher?" Jan explained:

\section{After his first presentation:}

"A bit frightened... it has been a year since I have been in front of the class performing the teaching lecture."

\section{After his final presentation:}

"My school mentor complimented me."
Teacher's evaluation of Jan's skills and knowledge [Scale 1 to 5]

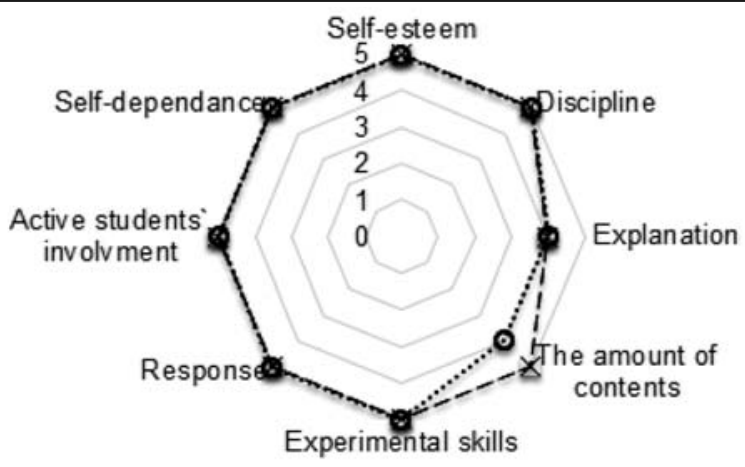

-..... First presentation $\quad-\star x-$. Final presentation

To the question "How did you perceive the course of the lesson with Ina in the role of chemistry teacher?" Jan's school mentor explained:

\section{After his first presentation:}

"Jan's teacher plan was correctly prepared in advance regarding the content and timetable. He was able to give brief and effective instructions to the students. Worksheets were appropriately prepared in advance; consequently, students were able to complete them independently, and then they were all checked at the end of the lesson. Therefore, students were active throughout the teaching process."

\footnotetext{
After his final presentation:

"Jan carried out the lesson independently. Prior to his lesson, he attended the observation of my class, and then he repeated the same topic. He carried out experimental group work successfully; the instructions were clearly and briefly delivered in advance. The results of the experiments were analysed with the students and therefore they successfully concluded the teaching lesson together."
} 
students in the lesson, thereby she described her improvement in various areas also in her comment. The opinion of Sara's teacher mentor was very similar; she gave her very good marks regarding almost all important characteristics observed and pointed out her improvement regarding confidence as well as the quality of teaching.

\section{3. Example 3: $4^{\text {th }}$-year student-teacher Jan}

It is clear from Table 5, that at his first presentation, the student-teacher Jan had evaluated all of his influential characteristics much more strictly than his school mentor did. Jan was not satisfied especially with his ability to clearly explain the topics thought; he commented to per- ceive himself as being frightened in the classroom after one-year pause since last practical pedagogical training in his third year of the study.

It can be seen from Table 5, that the situation had changed during the time of practical pedagogical training, as at Jan's final presentation, he was very satisfied with his lesson. Jan and his mentor's opinions were quite consistent, except regarding Jan's experimental skills and the suitability of Jan's explanation of the topic taught.

\section{4. Example 4: $4^{\text {th }}$-year student-teacher Mara}

It is clear from Table 6 that Mara had seen her suitability of explanation of the topic taught to be extremely

Table 6. Mara's self-evaluation of her skills and knowledge in specific fields at her first and final presentation during their PPT in comparison with the evaluation of her school mentor

Mara self-evaluation of her skills and knowledge [Scale 1 to 5]

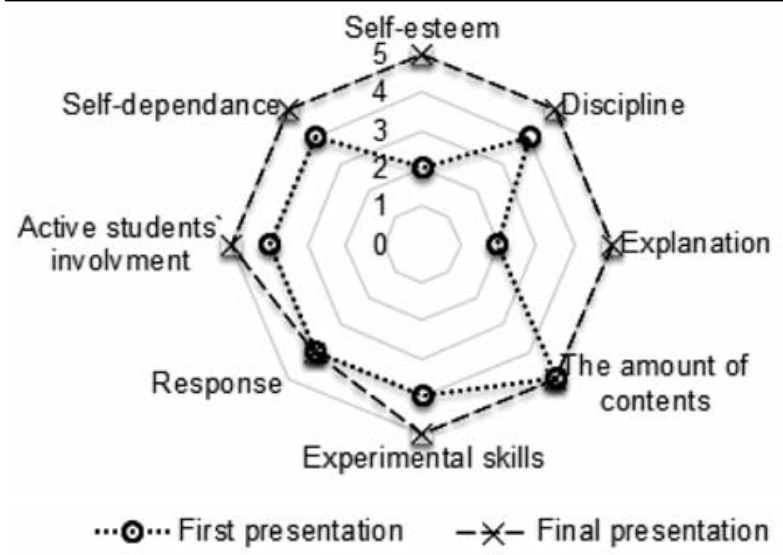

To the question "How did you perceive the course of the lesson in the role of chemistry teacher?" Mara explained:

\section{After her first presentation:}

"My first lesson presentation after one year outside the school practice. I feel I am able to carry out the teaching lesson appropriately, but I do need my teacher mentor to supervise me and give me a proper advice where needed."

\section{After her final presentation:}

"My last day of practical pedagogical training. I am full of new impressions and experiences. I feel I am no longer so nervous, and I have gained self-confidence."

\section{Teacher's evaluation of Mara's skills and knowledge} [Scale 1 to 5]

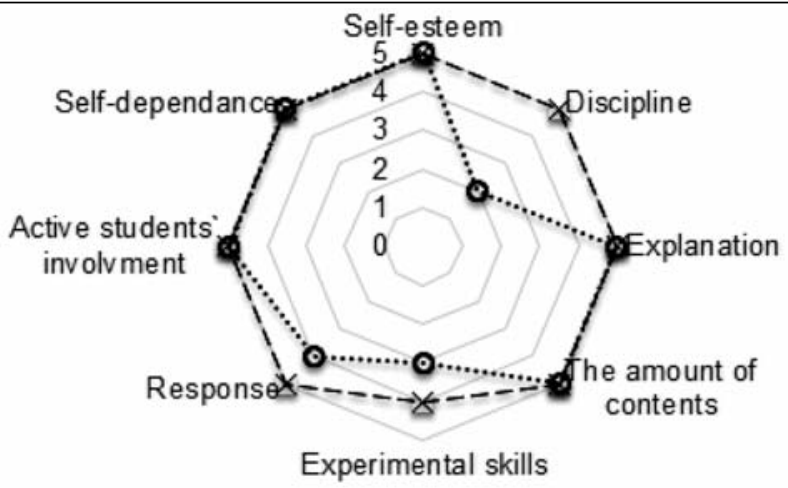

..๑... First presentation $\quad-\star \star-$ Final presentation

To the question "How did you perceive the course of the lesson with Ina in the role of chemistry teacher?" Mara's school mentor explained:

\section{After her first presentation:}

"In the future, Mara should work on step-by-step explanations of new chemical concepts introduced to the students during her lesson. For the whole image of the teaching lesson, it would be beneficial to add visual elements for better introducing and launching the new chemistry topics. There were some troubles with the time component of the teaching plan, which consequently was not appropriately carried out. She had quite a few problems with correct use of Slovenian language, as she spoke in a dialect."

\section{After her final presentation:}

"Mara should try to show a little bit more enthusiasm while teaching in the classroom. Consequently, the atmosphere in the classroom would be improved. The lesson should be more compact. In these terms, she should try to connect the parts of the lesson more tightly. However, she improved her teaching image in comparison to the last year of her PPT in our school. I recommend that she works on developing her natural body language when performing the teaching process." 
low at her first presentation, and she consequently also marked her self-esteem extremely low. Her school mentor did not evaluate her very well either, since she detected troubles with introducing and launching the new topics, as well as with the time component of the teaching plan and the discipline in the classroom.

At her last presentation, both Mara and her teacher mentor changed their opinions as can be seen in Table 6 . All the important characteristics were marked excellent by her teacher mentor, except in the case of Mara's experimental skills, where she can still improve. In the opinion of her school mentor, it is also important that in the future, she Mara shows more enthusiasm while teaching in the classroom.

\section{5.Example 5: $4^{\text {th }}$-year student-teacher Ula}

At her first presentation, it is clear from Table 7, that Ula was not satisfied with her teaching and that she had perceived all of her influential characteristics more strictly than her teacher mentor had. From her comment it is obvious, that she felt a relieve after her first lesson as she describes, that feels less nervous and to gain more control over the situation in the classroom.

Table 7. Ula's self-evaluation of her skills and knowledge in specific fields at her first and final presentation during their PPT in comparison with the evaluation of her school mentor

Ula's self-evaluation of her skills and knowledge [Scale 1 to 5]

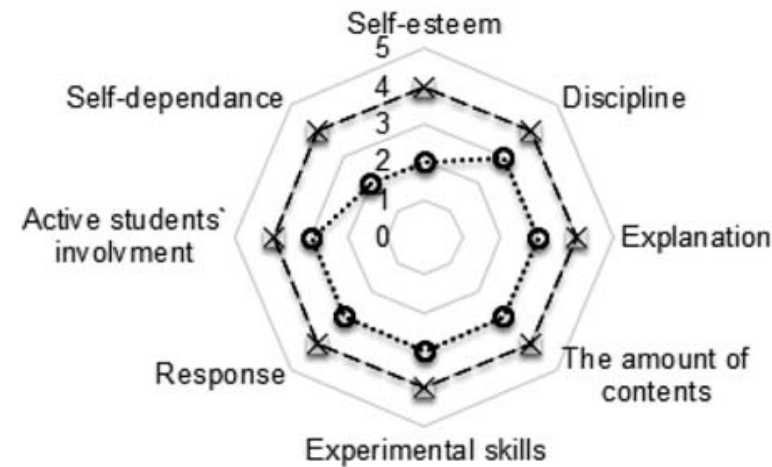

… First presentation $\quad-\star \star-$ Final presentation

To the question "How did you perceive the course of the lesson in the role of chemistry teacher?" Ula explained:

\section{After her first presentation:}

"The first teaching lessons have been successfully applied. I felt less nervous and have had more control over the situation in the classroom."

\section{After her final presentation:}

"The last day of my practical pedagogical training. I am full of new impressions; I am feeling much less nervous, and I have gained much self-confidence."
Teacher's evaluation of Ula's skills and knowledge [Scale 1 to 5]

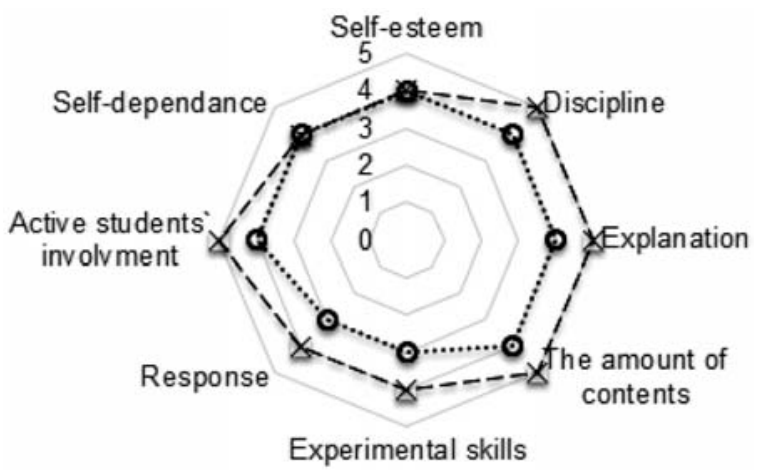

..๑... First presentation $\quad-\star-$ Final presentation

To the question "How did you perceive the course of the lesson with Ina in the role of chemistry teacher?" Ula's school mentor explained:

\section{After her first presentation:}

"Ula was able to prepare a compact teaching lesson plan, firstly, suitable for checking student's pre-knowledge and secondly for the introduction of new chemistry concepts, which has to be presented in the teaching lesson. Before this point, she had needed quite a lot of help, but after my careful review, she finally succeeded to prepare a good, complex and systematic teaching lesson plan.

During carrying out the teaching lesson in the class, she had to face some problems, regarding the discipline, but it was an expected and understandable situation, since the class is, in general, a bit problematic."

\footnotetext{
After her final presentation:

"Ula was able to prepare an interesting lesson presenting the chemistry concepts in a way interesting for teaching and learning. Her appropriate teaching plan comprises several teaching methods; the students were actively engaged by discussion and question making; she was able to include context-based teaching goals were students enjoy real self-reflection regarding ecological problems presented during the teaching and learning process."
} 
Ula's teaching improved during the practical pedagogical training, as the situation had changed at Ula's final presentation (Table 7). Ula described, that she gained new ideas and valuable experience during practical pedagogical training. In the case of four evaluated characteristics the teacher mentor saw Ula's ability even better than Ula did. These four characteristics were the following: the pre-service teacher's ability to establish discipline in class, the suitability of the pre-service teacher's explanation of the topic taught, the ability of the pre-service teacher to anticipate the appropriate amount of contents to present during the lesson and the pre-service teacher's ability to involve students actively. The mentor especially pointed out that Ula's teaching plan involved different teaching methods and that the students were actively engaged by discussion and question making.

Regarding the $4^{\text {th }}$-year student-teachers' PPT, it can be summarized from the overall results (Table 2), as well as from the analysis of individual teacher-students' reflections (Tables 3-7), that the school mentors were far less strict in evaluation of the student-teachers' performances in the class. All the teacher mentor's observations, especially regarding the students' first presentations, were far less demanding and much more indulgent regarding the student's behaviour in the class than the student-teachers' views of their selves were. However, regarding school mentor's and student-teachers' views of the last lesson in the class during their practical pedagogical training, there were far more matching reviews seen in comparison with their evaluations obtained at the first lessons in the class. The mentors' comment in the tables are in most cases also much longer than the comments of the student-teachers. The focus of student-teachers' comments, especially after their first lesson, is mostly about their self-esteem. Student-teachers report about their low confidence after oneyear brake after the practical pedagogical training in the third year of their studies, they claim to be nervous, to be frighten during teaching, while in the case of the mentors, they are more specific and report about different skills by student-teachers, e.g. structure of chemistry lesson, students' active involvement, discipline in the classroom, student-teachers' enthusiasm during teaching, etc..

\section{Conclusion}

This investigation presents $4^{\text {th }}$-year pre-service chemistry teachers' development during their second-year experience with teaching during their PPT from their own perspective as well as from that of their school mentors. In particular, it focused on the monitoring of pre-service chemistry teachers' first and last chemistry lesson during their PPT based on their own and their school mentors' perceptions of eight characteristics of pre-service teachers' development measured by the "Questionnaire for monitoring students' progress". ${ }^{7}$
The results revealed that after their first chemistry lecture pre-service teachers and their school mentors estimated similar values of four of eight student-teacher characteristics, e.g. no statistically significant differences found for the explanation of the chemistry topic taught, their experimental skills, their ability for providing an appropriate response to the students in the classrooms and their self-dependence in preparing for the lesson. However, pre-service teachers seem to be stricter than their school mentors are; statistically significant differences found in the evaluation of their appearance of self-esteem while conducting the lessons and ability to establish discipline in class during lesson, as well as their ability to anticipate the appropriate amount of contents to present during the lesson and to involve students actively. According to the results following the last chemistry lecture during PPT, it can be concluded that pre-service teachers gained more realistic estimations of their knowledge and skills with regard to the eight observed characteristics, when compared to their school mentors' perception, as the statistically significant difference was observed only in their evaluation of their ability to anticipate the appropriate amount of contents to present during the lesson. From the content point of comments, it can be concluded, that mentors' comments in the tables are in most cases longer than the comments of the student-teachers. Student-teachers' comments, especially after their first lesson, are mostly about their self-esteem, while in the case of the mentors, they are more specific and report about different skills by student-teachers, e.g. structure of chemistry lesson, teaching methods, students' active involvement, discipline in the classroom, student-teachers' enthusiasm during teaching, etc. When focusing on specific characteristics, the results are in line with previous research findings, ${ }^{7}$ in which the lowest value by pre-service teacher was also ascribed to their ability to establish discipline in the classroom and higher grades were ascribed to their ability to involve students actively in the lesson, followed by their self-dependence in preparing for the lesson.

Similarly, to previous studies ${ }^{17}$ it can be concluded that school mentors' feedback to student-teachers is a very important part of PPT, especially because they observe student-teachers' progress from a broader, more holistic perspective of their future profession - chemistry teacher. Therefore, sustained efforts should be focused on productive school-university collaboration, but also to raising of the awareness for the need of in-service chemistry teachers' sustainable education in their subject area in relation to recent findings from chemical education research, e.g. studying the impact of different experimental methods in chemistry teaching on school practice, ${ }^{24,25}$ studying the impact of the online knowledge assessment system on students' knowledge, ${ }^{26}$ the development of concept maps as learning materials to foster students' meaningful learning of organic reactions. ${ }^{27}$ 


\section{References}

1. M. S. Trevisan, Am. J. Eval. 2004, 25, 255-272. https://doi.org/10.1177/109821400402500212

2. T. Lawson, M. Çakmak, M. Gündüz, H. Busher, Eur. J. Teach. Educ. 2015, 38, 392-407. https://doi.org/10.1080/02619768.2014.994060

3. T. Hascher, G. Hagenauer, Int. J. Educ. Res. 2016, 77, 15-25. https://doi.org/10.1016/j.ijer.2016.02.003

4. M. Beeth, E. Adadan, J. Sci. Teacher Educ. 2006, 17, 103-120. https://doi.org/10.1007/s10972-006-9013-8

5. M. Poulou, Eur. J. Teach. Educ. 2007, 30, 91-110. https://doi.org/10.1080/02619760600944993

6. A. Maskan1, R. Efe, J. Turk. Sci. Educ. 2011, 8, 64-77.

7. K. S. Wissiak Grm, V. Ferk Savec, Acta Chim. Slov. 2014, 61, 729-739.

8. V. Ferk Savec, K.S.Wissiak Grm, in: I. Devetak, S. A. Glažar (Eds.): Learning with understanding in the chemistry classroom, Springer, Dordrecht, 2014, pp. 375-395. https://doi.org/10.1007/978-94-007-4366-3_18

9. T. Kwan, F. Lopez-Real, Asia-Pac. J. Teach. Educ. 2005, 33, 275-287. https://doi.org/10.1080/13598660500286267

10. T. Kwan, F. Lopez-Real, Teach. Teach. Educ. 2010, 26, 722-731. https://doi.org/10.1016/j.tate.2009.10.008

11. R. N. Stanulis, K. T. Ames, Prof. Educ. 2009, 33, 28-38.

12. A. Ambrosetti, J. Dekkers, Aust. J. Teach. Educ. 2010, 35, $42-55$.

13. J. Worthy, Int. J. Qual. Stud. Educ. 2005, 18, 379-398. https://doi.org/10.1080/09518390500082699
14. G. T. M. Ten Dam, S. Blom, Teach. Teach. Educ. 2006, 22, 647-660. https://doi.org/10.1016/j.tate.2006.03.003

15. D. J. Trumbull, K. Fluet, Teach. Teach. Educ. 2008, 24, 1672-1685. https://doi.org/10.1016/j.tate.2007.12.001

16. T. H. Levine, Teach. Teach. Educ. 2011, 27, 930-941. https://doi.org/10.1016/j.tate.2011.03.004

17. T. Lawson, M. Çakmak, M. Gündüz, H. Busher, Eur. J. Teach. Educ. 2015, 38, 392-407. https://doi.org/10.1080/02619768.2014.994060

18. F. Frost, M. Prenzel, T. Seidel, in: L. Ostern, K. Smith, R. Ryghaug, T. Krüger, M. B. Postholm (Eds.): Teacher education research between national identity and global trends, Akademika, Trondheim, 2013, pp. 139-162.

19. T. Hascher, F. Hofmann, in: K.-H. Arnold, A. Gröschner, T. Hascher (Eds.): Pedagogical field experiences in teacher education, Waxmann, Münster, 2014, pp. 257-276.

20. T. Hascher, G. Hagenauer, Int. J. Educ. Res. 2016, 77, 15-25. https://doi.org/10.1016/j.ijer.2016.02.003

21. T. Hascher, C. Kittinger, in: K.-H. Arnold, A. Gröschner, T. Hascher (Eds.): Pedagogical field experiences in teacher education, Waxmann, Münster, 2014, pp. 221-235.

22. Z. Shechtman, M. Levy, J. Leichtentritt, J. Educ. Res. 2005, 98, 144-155. https://doi.org/10.3200/JOER.98.3.144-155

23. I. Timoštšuk, A. Ugaste, Teach. Teach. Educ. 2010, 26, 1563-1570. https://doi.org/10.1016/j.tate.2010.06.008

24. M. Vrtačnik, N. Gros, Acta Chim. Slov. 2013, 60, 209-220.

25. A. Logar, V. Ferk Savec, Acta Chim. Slov. 2011, 58, 866-875

26. B. Kralj, S. A. Glažar, Acta Chim. Slov. 2013, 60, 433-441.

27. B. Šket, S. A. Glažar, J. Vogrinc, Acta Chim. Slov. 2015, 62, 462-472. https://doi.org/10.17344/acsi.2014.1148.

\section{Povzetek}

V članku predstavljena raziskava se ukvarja s samo-evalvacijo napredka med praktičnim pedagoških usposabljanjem bodočih učiteljev kemije, študentov četrtega letnika, v primerjavi z mnenjem njihovih mentorjev na šoli. Vzorec sestavlja 21 bodočih učiteljev kemije in 21 njihovih mentorjev, izkušenih učiteljev kemije na osnovnih šolah. Za namen spremljanja razvoja bodočih učiteljev kemije med praktičnim pedagoških usposabljanjem so bodoči učitelji in njihovi mentorji izpolnjevali »Vprašalnik za spremljanje razvoja bodočih učiteljev kemije«, ki temelji na evalvaciji osmih karakteristik strokovnega razvoja učiteljev kemije. Rezultati kažejo, da so bili bodoči učitelji kemije v samo-evalvaciji bolj strogi od svojih mentorjev, še posebno po prvi izvedeni uri pouka kemije, medtem ko so bile ocene po zadnji izvedeni uri podobne z ocenami mentorjev glede večine ocenjevanih karakteristik. Podrobneje je predstavljen razvoj petih naključno izbranih bodočih učiteljev kemije iz njihovega osebnega vidika, kakor tudi iz perspektive njihovih mentorjev. 